\title{
Mikrobiota Usus, Prebiotik, Probiotik, dan Sinbiotik pada Manajemen Obesitas
}

\section{Gut Microbiota, Prebiotics, Probiotics, and Synbiotics in Management of Obesity}

\author{
Chika Dewi Haliman $^{* 1}$, Silvia Alfinnia ${ }^{1}$
}

\begin{abstract}
ABSTRAK
Latar Belakang: Usus manusia merupakan tempat tinggal berbagai jenis mikroorganisme baik mikroorganisme menguntungkan maupun merugikan yang membentuk suatu mikrobiota. Mikrobiota usus mempunyai peranan penting terhadap kesehatan manusia, salah satunya menurunkan resiko obesitas.

Tujuan: Tujuan penulisan kajian pustaka ini adalah untuk menjabarkan peran mikrobiota usus dalam menurunkan resiko obesitas baik melalui pemberian prebiotik, probiotik, maupun sinbiotik.

Metode: Penelusuran literatur dilakukan melalui mesin pencari Google Scholar menggunakan kata kunci 'obesity', 'prebiotic', 'probiotic', 'synbiotic', dan 'gut microbiota' pada jurnal nasional maupun internasional. Dari hasil pencarian menggunakan kata kunci tersebut didapatkan 11.800 artikel

Ulasan: Hasil literature review menunjukkan bukti bahwa mikrobiota usus yang seimbang memiliki peran dalam menjaga kesehatan serta menurunkan resiko obesitas dengan mempengaruhi metabolisme energi, absorbsi zat gizi, integritas dinding usus, dan adipogenesis. Probiotik dapat menghambat pertumbuhan patogen usus serta meningkatkan sistem imun. Prebiotik berperan dalam mencegah overexpression beberapa gen yang berhubungan dengan adiposa, menurunkan nafsu makan dan massa lemak tubuh. Sinbiotik merupakan gabungan antara probiotik dan prebiotik yang memiliki efek lebih baik karena dengan adanya prebiotik, mikroorganisme probiotik memiliki toleransi yang lebih tinggi terhadap kondisi lingkungan seperti oksigenasi, $\mathrm{pH}$, dan suhu dalam usus. Beberapa penelitian selama minimal 12 minggu menggunakan dosis probiotik dibawah $10^{8} \mathrm{cfu} / \mathrm{hari}$ mampu memunculkan efek penurunan lemak adipose. Sedangkan untuk dosis prebiotik antara 12-21 gr/hari mampu memperbaiki regulasi glukosa pada dewasa obesitas.

Kesimpulan: Modifikasi menggunakan prebiotik dapat memicu produksi serta pelepasan bentuk aktif dari GLP1, penurunan ghrelin dan peningkatan PYY yang dapat menurunkan nafsu makan dan asupan energi. Modifikasi menggunakan probiotik dapat menurunkan absorbsi lemak, yang akan menyebabkan penurunan lemak abdomen. Sedangkan modifikasi menggunakan sinbiotik dapat menurunkan nafsu makan setelah peningkatan kadar GLP-1 dan PYY melalui mekanisme peningkatan produksi butirat (SCFA) oleh probiotik.
\end{abstract}

Kata kunci: mikrobiota usus, prebiotik, probiotik, sinbiotik, obesitas

\begin{abstract}
Background: Human intestine is the place of various types of microorganisms both beneficial and harmful microorganisms that form a microbiota. The intestinal microbiota has an important role in human health, one of which is reducing the risk of obesity.

Objectives: The objective of this literature review is to describe the role of intestinal microbiota in reducing the risk of obesity through both prebiotics, probiotics, and synbiotics.

Methods: Literature searches were carried out through the Google Scholar search engine using the keywords "obesity", "prebiotic", "probiotic", "synbiotic", and "gut microbiota" in national and international journals. From the search results using these keywords, 11,800 articles were found.

Discussions: The results of this literature review show evidence that a balanced intestinal microbiota has a role in maintaining health and reducing the risk of obesity by affecting energy metabolism, nutrient absorption, the integrity of the gut barrier, and adipogenesis. Probiotics can inhibit the growth of intestinal pathogens and enhance the immune system. Prebiotics play a role in preventing overexpression of some genes associated with adipose, decreasing appetite and body fat mass. Synbiotics are a combination of probiotics and prebiotics which are believed to have a better effect than probiotics or prebiotics.
\end{abstract}


Conclusions: Modifications using prebiotics can trigger the production and release of active forms of GLP 1 , decreased ghrelin, and increased PYY which can reduce appetite and energy intake. Modifications using probiotics can reduce fat absorption, which will cause a decrease in abdominal fat. While modification using synbiotics can reduce appetite after increasing GLP-1 and PYY levels through a mechanism of increasing butyrate production (SCFA) by probiotics.

Keywords: gut microbiota, prebiotic, probiotic, synbiotic, obesity

\author{
*Koresponden: \\ chika.dewi.haliman-2016@fkm.unair.ac.id \\ Chika Dewi Haliman \\ ${ }^{1}$ Departemen Gizi Kesehatan, Fakultas Kesehatan Masyarakat, Universitas Airlangga, Kampus C Mulyorejo, \\ 60115, Surabaya, Jawa Timur, Indonesia
}

\title{
PENDAHULUAN
}

Obesitas adalah salah satu masalah kesehatan masyarakat yang prevalensinya mulai meningkat di negara berkembang, salah satunya Indonesia. Prevalensi obesitas pada kelompok dewasa usia > 18 tahun di Indonesia mengalami peningkatan dari 14,8\% pada tahun 2013 menjadi 21,8\% pada tahun 2018 (Balitbangkes RI, 2018). Obesitas merupakan masalah kompleks yang melibatkan gaya hidup, lingkungan, dan genetic (Mahan and Raymond, 2017). Obesitas sendiri disebabkan oleh ketidakseimbangan antara asupan energi dan pengeluaran energi yang menyebabkan adanya penumpukan massa lemak pada tubuh. Berdasarkan standar Asia Pasific, BMI didefinisikan sebagai Indeks Massa Tubuh (IMT) $\geq 25 \mathrm{~kg} / \mathrm{m}^{2}$.

Usus manusia merupakan tempat tinggal berbagai jenis mikroorganisme. Jumlah dan jenis mikroorganisme bervariasi sesuai dengan bagian usus. Kolon merupakan tempat yang memiliki jumlah dan jenis mikroorganisme paling banyak, yaitu sekitar $10^{13}-10^{14}$ mikroorganisme(Power et al., 2014). Beberapa penelitian menunjukkan adanya peran mikrobiota usus dalam perkembangan kejadian obesitas (Kadooka et al., 2013)'(Parnell and Reimer, 2013)'(Rabiei et al., 2018)

Modifikasi mikrobiota usus menggunakan prebiotik, probiotik, maupun sinbiotik dapat menjadi salah satu strategi alternatif untuk menurunkan resiko obesitas. Prebiotik merupakan bahan fermentasi untuk mikroorganisme hidup yang dapat memberikan perubahan spesifik baik komposisi maupun aktivitas dalam mikrobiota usus (Vyas and Ranganathan, 2012). Probiotik merupakan mikroorganisme hidup yang ketika dikonsumsi dalam jumlah yang tepat dapat memberikan manfaat kesehatan (Gibson et al., 2010). Kombinasi antara probiotik dan prebiotik memiliki potensi untuk menginduksi lebih banyak substansi pada mikrobiota usus dan sel inang daripada asupan prebiotik atau probiotik saja (Brahe, Astrup and Larsen, 2016).

Literature review ini bertujuan untuk menjelaskan peran mikrobiota usus dalam menurunkan resiko obesitas baik melalui pemberian prebiotik, probiotik, maupun sinbiotik.

\section{METODE}

Penelusuran literatur dilakukan melalui mesin pencari Google Scholar menggunakan kata kunci 'obesity', 'prebiotic', 'probiotic', 'synbiotic', dan 'gut microbiota' pada jurnal nasional maupun internasional. Dari hasil pencarian menggunakan kata kunci tersebut didapatkan 11.800 artikel. Kemudian diambil 5 artikel yang sesuai dengan kriteria inklusi yaitu penelitian dengan desain Randomized Controlled Trial (RCT) dan dilakukan pada subjek kelompok usia dewasa. Literatur yang ditelusuri adalah artikel yang diterbitkan pada 10 tahun terakhir. Namun, referensi tambahan yang terbit sebelum tahun 2009 juga dimasukkan apabila masih berhubungan dengan topik yang dibahas.

\section{HASIL DAN DISKUSI}

\section{Mikrobiota Usus}

Usus manusia menjadi tempat tinggal berbagai jenis mikroba terutama sel bakteri. Jumlah bakteri terbanyak berada pada bagian terakhir sistem pencernaan yaitu kolon (Ley, Peterson and Gordon, 2006). Hampir 90\% spesies bakteri yang menghuni usus manusia terbagi menjadi 2 filum, Firmicutes dan Bacteroidetes dengan genus yang paling banyak ditemukan adalah Clostridium, Enterococcus, Lactobacillus, Ruminococcus, Bacteroides, dan Prevotella (Power et al., 2014).

Mikrobiota usus memberikan manfaat kesehatan berupa kemampuan untuk ekstraksi energi dari serat yang tidak dapat dicerna oleh tubuh, mensintesis vitamin, dan regulasi sistem imun (Lozupone et al., 2004). Mikrobiota usus meningkatkan fungsi barrier usus dan melindungi translokasi patogen dengan melakukan kompetisi untuk mendapatkan nutrisi, tempat perlekatan dan produksi senyawa antimikroba (Markowiak and Ślizewska, 2017). Mikrobiota usus juga memiliki peran penting dalam metabolisme glukosa dan asam lemak, serta terlibat dalam modifikasi sekresi hormon untuk meningkatkan rasa kenyang (Cani et al., 2006; Kellow, Coughlan and Reid, 2014). 


\section{Modifikasi Mikrobiota Usus}

Intervensi yang sederhana, aman, dan efektif sangat dibutuhkan dalam mencegah dan menangani obesitas serta kelainan metabolik lainnya. Mikrobiota usus manusia dan metabolitnya dapat mempengaruhi fisiologi, homeostasis energi, proses inflamasi, serta fungsi imun tubuh. Penggunaan prebiotik, probiotik, maupun sinbiotik akan menjadi salah satu strategi gizi yang penting pada manajemen obesitas dan kelainan metabolik lain. Meskipun jumlah dan jenis bakteri pada setiap individu relatif tetap, namun modifikasi mikrobiota usus dapat dilakukan melalui modifikasi diet. Prebiotik dan probiotik dapat mempengaruhi mikrobiota usus melalui jalur yang spesifik.

Prebiotik dapat didefinisikan sebagai makanan yang tidak dapat dicerna yang memberikan manfaat kesehatan (FAO, 2015). Makanan yang dikategorikan sebagai prebiotik harus mempunyai sifat tidak dapat dihidrolisis oleh enzim pencernaan ataupun di absorbsi di bagian atas saluran gastrointestinal, serta dapat menjadi substrat untuk satu atau lebih bakteri menguntungkan di kolon (FAO, 2015). Prebiotik pada umumnya terdiri dari inulin, fructooligosaccharides (FOS), dan galacto-oligosaccharides (GOS); prebiotik yang baru berkembang terdiri dari pati resisten, xylo-oligosaccharides, dan arabinoxylan-oligosaccharides (FAO, 2015). Efek dari prebiotik pada umumnya adalah stimulasi bakteri menguntungkan dan produksi Short Chain Fatty Acid (SCFA), meningkatkan absorbsi mineral, mempengaruhi metabolisme lemak dengan menekan enzim lipogenik dan menurunkan sintesis lipoprotein dan trigliserida (TG) (Jackson et al., 2004).

Probiotik adalah mikroorganisme hidup, yang ketika dikonsumsi dapat memberikan manfaat kesehatan baik melalui interaksi langsung dengan tubuh maupun secara tidak langsung dengan spesies bakteri lain (Brahe, Astrup and Larsen, 2016). Probiotik pada umumnya terdiri dari Bifidobacteria dan Lactobacillus(Rowland et al., 2010). Efek probiotik pada umumnya adalah eksklusi patogen melalui produksi bakterisida dan kompetisi untuk nutrisi dan tempat perlekatan, modulasi respon inflamasi melalui interaksi dengan sel imun di usus, dan modulasi ekspresi gen (Brahe, Astrup and Larsen, 2016). Sinbiotik memiliki potensi untuk menginduksi efek yang lebih substansial pada mikrobiota usus dan kesehatan manusia daripada asupan prebiotik atau probiotik saja, karena pemberian bakteri probiotik dalam kombinasi dengan komponen prebiotik yang merangsang kelangsungan hidup bakteri probiotik di saluran pencernaan (Brahe, Astrup and Larsen, 2016).

Tabel 1. Perbandingan Hasil Penelitian Modifikasi Mikrobiota Usus pada Obesitas

\begin{tabular}{|c|c|c|c|}
\hline Peneliti dan Tahun & $\begin{array}{c}\text { Judul dan Sampel } \\
\text { Penelitian } \\
\end{array}$ & Metode & Hasil \& Kesimpulan \\
\hline \multicolumn{4}{|l|}{ Modifikasi Probiotik } \\
\hline Rajkumar et al, 2014 & $\begin{array}{l}\text { Effect of Probiotic (VSL\#3) } \\
\text { and Omega-3 on Lipid } \\
\text { Profile, Insulin Sensitivity, } \\
\text { Inflammatory Markers, and } \\
\text { Gut Colonization in } \\
\text { Overweight Adults: A } \\
\text { Randomized, Controlled } \\
\text { Trial }\end{array}$ & $\begin{array}{l}\text { Desain } \\
\text { - Randomized, placebo } \\
\text { controlled trial } \\
\text { Intervensi } \\
\text { - Pemberian kapsul } \\
\text { plasebo, probiotik, } \\
\text { omega } 3 \text { dan } \\
\text { probiotik+omega3 } \\
\text { selama } 6 \text { minggu } \\
\text { Variabel } \\
\text { - Pemberian probiotik } \\
\text { (VSL \#3), omega3, } \\
\text { dan placebo } \\
\text { - Marker inflamasi, } \\
\text { serum glukosa, total } \\
\text { kolesterol, TG, HDL, } \\
\text { insulin resisten, hs- } \\
\text { CRP, mikrobiota usus } \\
\text { Analisis } \\
\text { - ANOVA }\end{array}$ & $\begin{array}{l}\text { Hasil } \\
\text { Kelompok suplemen } \\
\text { probiotik (VSL \# 3) } \\
\text { memiliki penurunan yang } \\
\text { signifikan dalam total } \\
\text { kolesterol, trigliserida, } \\
\text { LDL, dan VLDL dan } \\
\text { telah meningkatkan nilai } \\
\text { HDL (p <0,05). } \\
\text { Kesimpulan } \\
\text { Probiotik yang diberikan } \\
\text { dalam kombinasi dengan } \\
\text { omega-3 lebih efektif } \\
\text { daripada probiotik saja. } \\
\text { Namun, suplemen } \\
\text { omega-3 hanya } \\
\text { menunjukkan rarek } \\
\text { marginal pada semua } \\
\text { parameter. }\end{array}$ \\
\hline $\begin{array}{l}\text { Kadooka Y et al, } \\
2014\end{array}$ & \begin{tabular}{lrr} 
Effect of & \multicolumn{2}{c}{ Lactobacillus } \\
gasseri & SBT2055 in \\
fermented & milk on \\
abdominal adiposity in \\
adults in a randomised \\
controlled trial.
\end{tabular} & 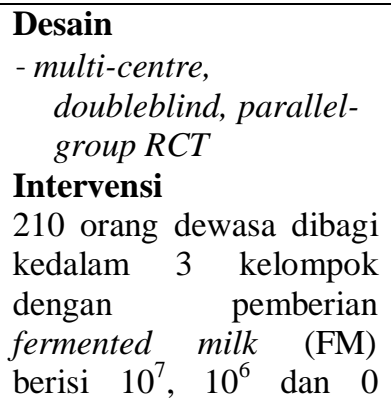 & $\begin{array}{l}\text { Hasil } \\
\text { Pada minggu ke } 12 \text {, } \\
\text { Lemak visceral } \\
\text { mengalami perubahan } \\
\text { dengan rata-rata } 8,5 \% \\
(95 \% \mathrm{CI}, \mathrm{p}<0,01) \text { dalam } \\
\text { kelompok dengan dosis } \\
10^{7}, \text { dan sebesar } 8,2 \% \\
(95 \% \mathrm{CI} \text {, p<0,01) pada } \\
\text { kelompok dengan dosis }\end{array}$ \\
\hline
\end{tabular}




\begin{tabular}{|c|c|c|c|}
\hline Peneliti dan Tahun & $\begin{array}{c}\text { Judul dan Sampel } \\
\text { Penelitian }\end{array}$ & Metode & Hasil \& Kesimpulan \\
\hline Modifikasi Probiotik & & $\begin{array}{l}\text { (kelompok kontrol) cfu } \\
\text { LG2055/g, dan diminta } \\
\text { untuk mengonsumsi } 200 \\
\text { g FM/hari selama } 12 \\
\text { minggu. } \\
\text { Variabel } \\
\text { - Pemberian probiotik } \\
\text { jenis Lactobacillus } \\
\text { gasseri SBT2055 } \\
\text { dengan dosis } 10^{7}, 10^{6} \\
\text { dan 0 (kelompok } \\
\text { kontrol) cfu LG2055/g } \\
\text { FM } \\
\text { - Lemak visceral, BMI, } \\
\text { lingkar perut, dan } \\
\text { massa lemak tubuh. } \\
\text { Analisis } \\
\text { - ANOVA } \\
\text { - Bonferroni multiple } \\
\text { comparisons }\end{array}$ & $\begin{array}{l}10^{6} \text {. BMI, lingkar perut, } \\
\text { dan massa lemak tubuh } \\
\text { juga menurun secara } \\
\text { signifikan pada kedua } \\
\text { kelompok. Pada } \\
\text { kelompok kontrol, tidak } \\
\text { satu pun dari parameter } \\
\text { menunjukkan penurunan } \\
\text { yang signifikan } \\
\text { Kesimpulan } \\
\text { Konsumsi probiotik jenis } \\
\text { LG2055 dengan dibawah } \\
10^{8} \text { cfu/hari menunjukkan } \\
\text { efek yang signifikan } \\
\text { terhadap penurunan } \\
\text { lemak adipose }\end{array}$ \\
\hline \multicolumn{4}{|l|}{ Modifikasi Prebiotik } \\
\hline $\begin{array}{l}\text { Parnell and Reimer, } \\
2009\end{array}$ & $\begin{array}{l}\text { Weight loss during } \\
\text { oligofructose } \\
\text { supplementation is } \\
\text { associated with decreased } \\
\text { ghrelin and increased } \\
\text { peptide YY in overweight } \\
\text { and obese adults }\end{array}$ & 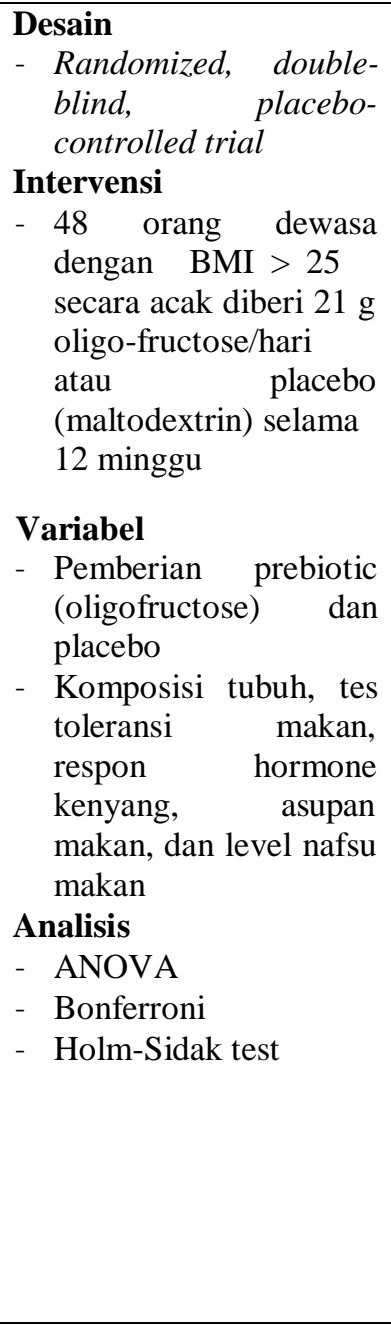 & 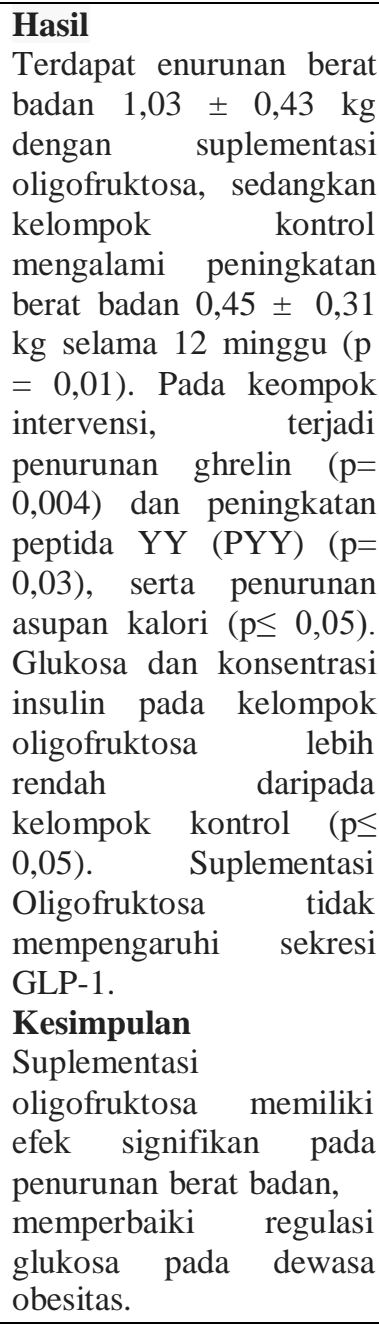 \\
\hline \multicolumn{4}{|l|}{ Modifikasi Sinbiotik } \\
\hline Stenman et al, 2016 & $\begin{array}{l}\text { Probiotic With or Without } \\
\text { Fiber Controls Body Fat Mass, } \\
\text { Associated With Serum } \\
\text { Zonulin, in } \\
\text { Overweight and ObeseAdults- } \\
\text { Randomized Controlled Trial }\end{array}$ & $\begin{array}{l}\text { Desain } \\
-\quad \text { Randomized, double- } \\
\quad \text { blind } \\
\text { Intervensi } \\
\text { - Pemberian 1) Plasebo, } \\
\quad \text { microcrystalline }\end{array}$ & $\begin{array}{l}\text { Hasil } \\
\text { Tidak ada perbedaan } \\
\text { yang signifikan antara } \\
\text { massa lemak tubuh dalam } \\
\text { populasi intervensi. } \\
\text { Untuk perubahan massa }\end{array}$ \\
\hline
\end{tabular}




\begin{tabular}{|c|c|c|c|}
\hline Peneliti dan Tahun & $\begin{array}{c}\text { Judul dan Sampel } \\
\text { Penelitian }\end{array}$ & Metode & Hasil \& Kesimpulan \\
\hline & & 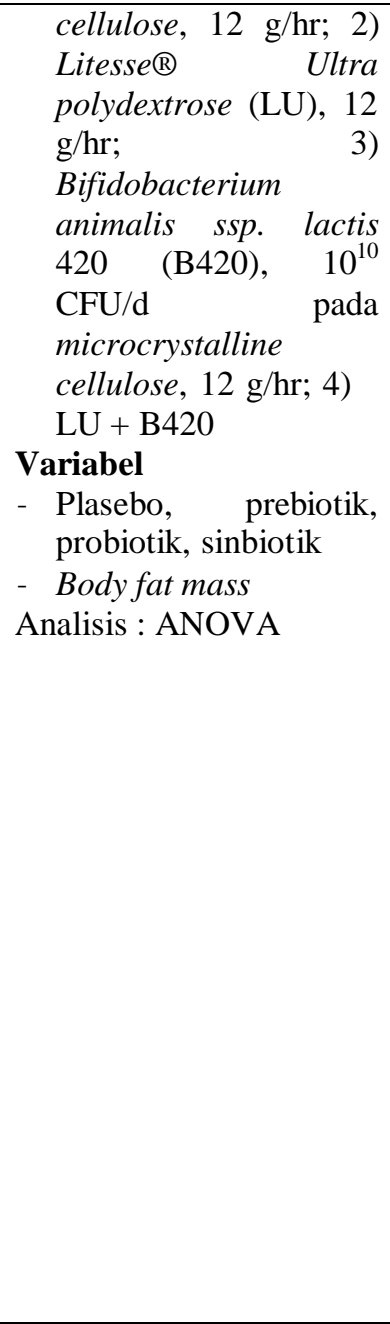 & 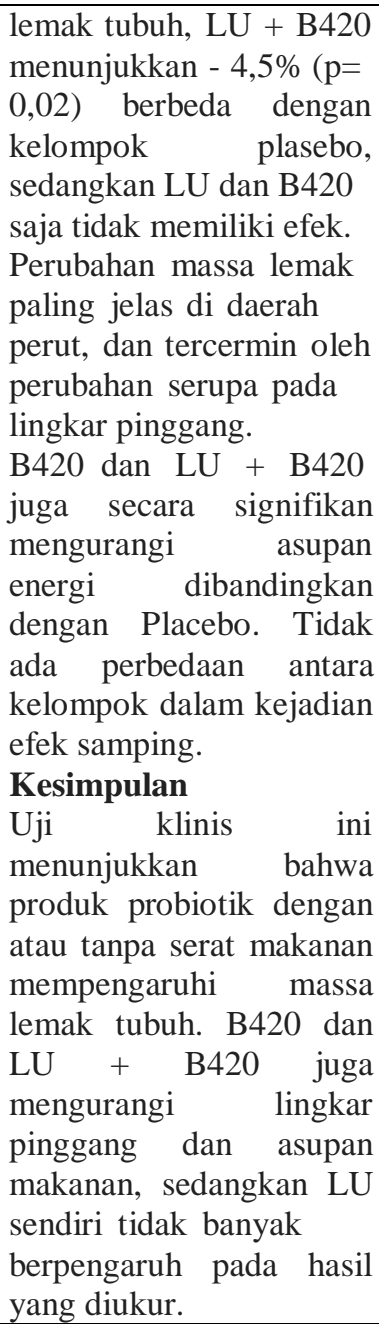 \\
\hline Rabiei et al, 2018 & $\begin{array}{l}\text { The Effects of Synbiotic } \\
\text { Supplementation on Body } \\
\text { Mass Index, Metabolic and } \\
\text { Inflammatory Biomarkers, } \\
\text { and Appetite in Patients } \\
\text { with Metabolic Syndrome: } \\
\text { A Triple-Blind Randomized } \\
\text { Controlled Trial }\end{array}$ & $\begin{array}{l}\text { Desain } \\
\text { - } \text { triple-blind } \\
\text { randomized clinical } \\
\text { trial } \\
\text { Intervensi } \\
\text { - } 46 \text { pasien dengan } \\
\text { metabolic syndrome } \\
\text { diberi kapsul sinbiotik } \\
\text { atau placebo, 2x sehari } \\
\text { selama } 3 \text { bulan, serta } \\
\text { diet penurunan beart } \\
\text { badan sinbiotik } \\
\text { Kapsul } \\
\text { mengandung } 7 \text { jenis } \\
\text { probiotik }\left(2 \times 10^{8}\right) \\
\text { ditambah } \\
\text { fructooligosakarida } \\
\text { sebagai prebiotik. } \\
\text { Variabel } \\
\text { - Pemberian kapsul } \\
\text { sinbiotik dan placebo, } \\
\text { diet penurunan berat } \\
\text { badan } \\
\text { Berat badan, BMI, } \\
\text { gula darah puasa } \\
\text { (GDP), insulin, profil } \\
\text { lipid, hs-CRP, IL-6, }\end{array}$ & $\begin{array}{l}\text { Hasil } \\
\text { Perubahan rata-rata berat, } \\
\text { BMI, GDP, insulin, } \\
\text { HOMA-IR, dan GLP-1 } \\
\text { antara kedua kelompok } \\
\text { signifikan (p <0,001). } \\
\text { Peptida YY (PYY) } \\
\text { meningkat secara } \\
\text { signifikan pada kelompok } \\
\text { sinbiotik (p<0,05). } \\
\text { Kecenderungan } \\
\text { penurunan berat badan } \\
\text { pada kelompok sinbiotik } \\
\text { signifikan sampai akhir } \\
\text { penelitian (p <0,001) } \\
\text { sementara itu kelompok } \\
\text { plasebo berhenti pada } \\
\text { minggu ke } 6 . \\
\text { Kesimpulan } \\
\text { Terapi sinbiotik dapat } \\
\text { memperbaiki status BMI, } \\
\text { GDP, resistensi insulin, } \\
\text { HOMA-IR, GLP-1, dan } \\
\text { PYY pada pasien dengan } \\
\text { sindroma metabolik. }\end{array}$ \\
\hline
\end{tabular}




\begin{tabular}{lll}
\hline Peneliti dan Tahun & $\begin{array}{c}\text { Judul dan Sampel } \\
\text { Penelitian }\end{array}$ & Metode \\
\hline & peptide YY (PYY), & Hasil \& Kesimpulan \\
& HOMA-IR, dan \\
& glucagon-like peptide- \\
& 1 (GLP-1) \\
& Analisis \\
& - Paired t test \\
& - Student t test \\
& - Multiple comparisons \\
& - Bonferroni post hoc \\
& test \\
\hline
\end{tabular}

\section{Hubungan Mikrobiota Usus dengan Obesitas}

Salah satu mekanisme untuk menjelaskan hubungan ini adalah hipotesis endotoksemia metabolik, yang menghubungkan mikrobiota usus dengan inflamasi tingkat rendah dan gangguan metabolic ('Rangueil Institute of Molecular Medicine, I 2 MR, U858 Inserm, IFR31, Toulouse, France, 2 Inserm U558, Toulouse, France', 2009). Beberapa penelitian menunjukkan adanya hubungan antara obesitas dan kelainan metabolik dengan barrier usus yang terganggu, yang dapat menyebabkan translokasi endotoksin (Stenman, Holma and Korpela, 2012). Pada penelitian yang dilakukan oleh Kadooka, asupan probiotik Lactobacillus gasseri SBT2055 (LG2055) menunjukkan penurunan lemak abdomen dan lemak subkutan, berat badan, BMI, lingkar pinggang dan pinggul, dan massa lemak tubuh. Hal ini disebabkan karena LG2055 mempengaruhi metabolisme energi dan status inflamasi tubuh melalui mikroba usus. LG2055 juga memiliki kemampuan untuk menurunkan absorbsi lemak, yang akan menyebabkan penurunan lemak abdomen (Kadooka et al., 2010).

Pada penelitian lain menunjukkan bahwa suplementasi inulin-type fructans dalam jangka waktu yang lama dapat berkontribusi dalam penurunan berat badan pada remaja dan dewasa overweight dan obesitas (Liber and Szajewska, 2013). Sedangkan pemberian suplementasi prebiotik inulin-type fructans selama 12 minggu tidak menunjukkan efek signifikan terhadap penurunan berat badan pada anak usia sekolah yang mengalami overweight dan obesitas (Liber and Szajewska, 2014).

Namun, Cani et al pada tahun 2006 menemukan bahwa konsumsi oligofructose sebanyak 16 gram/hari dibandingkan dengan plasebo (dextrin maltose) secara signifikan meningkatkan rasa kenyang selama sarapan dan makan malam, juga dapat mengurangi rasa lapar dan keinginan untuk makan lagi setelah makan malam. Asupan energi yang diukur lebih rendah 5\% ( $\mathrm{p}<0,05)$ setelah suplementasi oligofructose dibanding dengan placebo (Cani et al., 2006).

Prebiotik juga dapat mencegah overexpression beberapa gen yang berhubungan dengan adiposa dan inflamasi (Delzenne et al., 2011). Inulin-type fructans meningkatkan jumlah sel endokrin L di jejunum dan kolon pada tikus, dan memicu produksi serta pelepasan bentuk aktif dari GLP-1 and GLP-2 ke vena porta (Cani et al., 2009). Studi ekperimental menunjukkan bahwa GLP 1 bersama dengan prebiotik dapat menurunkan nafsu makan, massa lemak dan resistensi insulin hati, sedangkan GLP 2, berkontribusi terhadap penurunan permeabilitas dari dinding usus dan endotoksemia yang berhubungan dengan obesitas (Cani et al., 2009). Penurunan ghrelin dan peningkatan PYY juga dapat mempengaruhi penurunan asupan energi sehingga dapat berkontribusi terhadap penurunan berat badan pada individu yang mengalami obesitas (Parnell and Reimer, 2013). Sedangkan sinbiotik memungkinkan terjadinya fermentasi produk prebiotik oleh probiotik di kolon yang akan menghasilkan SCFA (asetat, propionat, dan butirat) (Patel and Dupont, 2015). SCFA memiliki peran penting dalam mempertahankan status kesehatan usus manusia serta memodulasi proses imun dan metabolik. SCFA adalah ligan untuk dua reseptor protein G (GPR41 dan GPR43), yang mengekspresikan variasi sel gastrointestinal dan menstimulasi sekresi hormon yang terlibat dalam regulasi asupan dan pengeluaran energy (Kellow, Coughlan and Reid, 2014). Ikatan antara SCFA dengan GPR41 meningkatkan produksi peptide YY dan GLP1, hormon yang menekan nafsu makan, menunda pengosongan lambung, dan meningkatkan sensitivitas insulin (Kellow, Coughlan and Reid, 2014). Sinbiotik juga dapat menurunkan nafsu makan setelah peningkatan kadar GLP-1 dan PYY melalui mekanisme peningkatan produksi butirat (SCFA) oleh probiotik (Yadav et al., 2013).

Probiotik juga diyakini dapat terlibat dalam regulasi metabolisme lemak karena memiliki kemampuan memproduksi enzim hidrolase garam empedu yang dapat mendekonjugasi asam empedu (Hill, Gahan and Begley, 2006). Dekonjugasi asam empedu kurang efisien dalam meningkatkan penyerapan lipid daripada asam empedu terkonjugasi (Hill, Gahan and Begley, 2006). Asam empedu dekonjugasi dieksresikan dalam jumlah yang lebih banyak dibandingkan asam empedu yang terkonjugasi (Hill, Gahan and Begley, 2006). Hal ini menyebabkan peningkatan penggunaan serum kolesterol di hati untuk sintesis asam empedu baru.

Pada penelitian yang dilakukan oleh Madjd pada tahun 2016, terdapat perbedaan signifikan total kolesterol dan kolesterol LDL pada kelompok intervensi (pemberian yogurt probiotik) dibandingkan dengan kelompok kontrol (pemberian yogurt rendah lemak) selama 12 minggu. Total kolesterol berkurang sebanyak $0,36 \pm 0,10 \mathrm{mmol} / \mathrm{L}$ pada kelompok intervensi, sedangkan pada kelompok control hanya berkurang $0,31 \pm 0,10$ 
$\mathrm{mmol} / \mathrm{L}(\mathrm{p}=0,024)$. Kolesterol LDL juga berkurang sebanyak 0,36 $\pm 0,10 \mathrm{mmol} / \mathrm{L}$ pada kelompok intervensi, sedangkan pada kelompok kontrol yang hanya berkurang $0.30 \pm 0.11 \mathrm{mmol} / \mathrm{L}$ ( $\mathrm{p}=0,018)$ (Madjd et al., 2016). Penelitian lain menunjukkan adanya peningkatan HDL pada kelompok probiotik sebesar 18,5\% $(P<0.01)$; penurunan LDL ( $\mathrm{p}<0,05)$, trigliserida, dan VLDL ( $\mathrm{p}<0,01)$ masing-masing sebesar 7,04\%;5,8\%, dan 12,98\% (Rajkumar et al., 2014).

Penelitian yang menggunakan probiotik untuk melakukan perubahan spesifik terhadap mikrobiota usus menunjukkan bahwa Angiopoetin related protein 4 (Angpt14), penghambat lipoprotein lipase meningkat pada tikus dengan diet tinggi lemak dan suplementasi L. paracasei. Angptl4 dapat menghambat uptake asam lemak dari sirkulasi ke jaringan adipose dan otot (Aronsson et al., 2010).

Individu yang mengonsumsi sinbiotik mengalami penurunan berat badan dalam jangka waktu lama, dibandingkan dengan plasebo. Hal ini dapat dijelaskan melalui efek sinbiotik terhadap nafsu makan. Penekanan nafsu makan, regulasi metabolism lemak, dan peningkatan penggunaan energi adalah mekanisme utama anti obesitas oleh komponen sinbiotik (Delzenne et al., 2011).

\section{KESIMPULAN}

Modifikasi mikrobiota usus memiliki peran dalam menurunkan resiko obesitas. Modifikasi menggunakan prebiotik dapat memicu produksi serta pelepasan bentuk aktif dari GLP-1 ke vena porta, penurunan ghrelin dan peningkatan PYY yang dapat menurunkan nafsu makan dan asupan energi. Modifikasi menggunakan probiotik dapat menurunkan absorbsi lemak, yang akan menyebabkan penurunan lemak abdomen. Sedangkan modifikasi menggunakan sinbiotik dapat menurunkan nafsu makan setelah peningkatan kadar GLP-1 dan PYY melalui mekanisme peningkatan produksi butirat (SCFA) oleh probiotik.

\section{ACKNOWLEDGEMENT}

Penulis mengucapkan terimakasih kepada panitia kegiatan Lomba NutResearch NUTRIBE 2019 yang telah mendukung terselesaikannya penulisan literature review ini tepat waktu tanpa ada hambatan yang berarti.

\section{REFERENSI}

Aronsson, L. et al. (2010) 'Decreased fat storage by Lactobacillus paracasei is associated with increased levels of angiopoietin-like 4 protein (ANGPTL4)', PLoS ONE, 5(9), pp. $1-7 . \quad$ doi: 10.1371/journal.pone.0013087.

Balitbangkes RI (2018) Hasil Utama Riset Kesehatan Dasar 2018, Kementrian Kesehatan Republik Indonesia.

Brahe, L. K., Astrup, A. and Larsen, L. H. (2016) 'Can We Prevent Obesity-Related Metabolic Diseases by Dietary Modulation of the Gut Microbiota?', American Society for Nutrition, 7, pp. 90-101. doi: 10.3945/an.115.010587.

Cani, P. D. et al. (2006) 'Oligofructose promotes satiety in healthy human: A pilot study', European Journal of Clinical Nutrition, 60(5), pp. 567-572. doi: 10.1038/sj.ejcn.1602350.

Cani, P. D. et al. (2009) 'Changes in gut microbiota control inflammation in obese mice through a mechanism involving GLP-2-driven improvement of gut permeability’, Gut, 58(8), pp. 1091-1103. doi: 10.1136/gut.2008.165886.

Delzenne, N. M. et al. (2011) 'Targeting gut microbiota in obesity: Effects of prebiotics and probiotics', Nature Reviews Endocrinology. Nature Publishing Group, 7(11), pp. 639-646. doi: 10.1038/nrendo.2011.126.

FAO (2015) 'Food and Agriculture Organization of the United Nations FAO Technical Meeting on', pp. 1-12.

Gibson, G. R. et al. (2010) 'Dietary prebiotics: current status and new definition', Food Science \& Technology Bulletin: Functional Foods, 7(1), pp. 1-19. doi: 10.1616/1476-2137.15880.

Hill, C., Gahan, C. G. M. and Begley, M. (2006) 'Bile salt hydrolase activity in probiotics.', Applied and environmental microbiology, 72(3), pp. 1729-38. doi: 10.1128/AEM.72.3.1729-1738.2006.

Jackson, K. G. et al. (2004) 'The effect of the daily intake of inulin on fasting lipid, insulin and glucose concentrations in middle-aged men and women Jackson KG, Taylor GRJ, Clohessy AM, Williams CM. BrJ Nutri 1999;82:23?30', Journal of Manipulative and Physiological Therapeutics, 23(5), p. 375. doi: 10.1016/s0161-4754(00)90230-6.

Kadooka, Y. et al. (2010) 'Regulation of abdominal adiposity by probiotics (Lactobacillus gasseri SBT2055) in adults with obese tendencies in a randomized controlled trial', European Journal of Clinical Nutrition. Nature Publishing Group, 64(6), pp. 636-643. doi: 10.1038/ejcn.2010.19.

Kadooka, Y. et al. (2013) 'Effect of Lactobacillus gasseri SBT2055 in fermented milk on abdominal adiposity in adults in a randomised controlled trial.', The British journal of nutrition, 110(9), pp. 1696- 1703. doi: 10.1017/S0007114513001037.

Kellow, N. J., Coughlan, M. T. and Reid, C. M. (2014) 'Systematic Review Metabolic benefits of dietary prebiotics in human subjects : a systematic review of randomised controlled trials', pp. 1147-1161. doi: $10.1017 /$ S0007114513003607. 
Ley, R. E., Peterson, D. A. and Gordon, J. I. (2006) 'Ecological and evolutionary forces shaping microbial diversity in the human intestine', Cell, 124(4), pp. 837-848. doi: 10.1016/j.cell.2006.02.017.

Liber, A. and Szajewska, H. (2013) 'Effects of inulin-type fructans on appetite, energy intake, and body weight in children and adults: Systematic review of randomized controlled trials', Annals of Nutrition and Metabolism, 63(1-2), pp. 42-54. doi: 10.1159/000350312.

Liber, A. and Szajewska, H. (2014) 'Effect of oligofructose supplementation on body weight in overweight and obese children: A randomised, double-blind, placebo-controlled trial', British Journal of Nutrition, 112(12), pp. 2068-2074. doi: 10.1017/S0007114514003110.

Lozupone, C. et al. (2004) 'Diversity, stability and resilience of the human gut microbiota Catherine',

Appita journal, 57(3), pp. 224-227. doi: 10.1038/nature11550.Diversity.

Madjd, A. et al. (2016) 'Comparison of the effect of daily consumption of probiotic compared with low-fat conventional yogurt on weight loss in healthy obese women following an energy-restricted diet: a randomized controlled trial.', American Journal of Clinical Nutrition, 103(2), pp. 323-329. doi: 10.3945/ajcn.115.120170.

Mahan, L. K. and Raymond, J. L. (2017) Krause's Food \& The Nutrition Care Process. 14th editi, Elsevier. 14th editi.

Markowiak, P. and Ślizewska, K. (2017) 'Effects of probiotics, prebiotics, and synbiotics on human health', Nutrients, 9(9). doi: 10.3390/nu9091021.

Parnell, J. A. and Reimer, R. A. (2013) 'Weight loss during oligofructose supplementation is associated with decreased ghrelin and increased peptide YY in overweight and obese adults 2', 89(6), pp. 1751-1759. doi: 10.3945/ajen.2009.27465. Weight.

Patel, R. and Dupont, H. L. (2015) 'New approaches for bacteriotherapy: Prebiotics, new-generation probiotics, and synbiotics', Clinical Infectious Diseases, 60(Suppl 2), pp. S108-S121. doi: 10.1093/cid/civ177.

Power, S. E. et al. (2014) 'Intestinal microbiota, diet and health', British Journal of Nutrition, 111(3), pp. 387402. doi: $10.1017 / \mathrm{S} 0007114513002560$.

Rabiei, S. et al. (2018) 'The Effects of Synbiotic Supplementation on Body Mass Index , Metabolic and Inflammatory Biomarkers, and Appetite in Patients with Metabolic Syndrome: A Triple-Blind Randomized Controlled Trial The Effects of Synbiotic Supplementation on Body Mass Index'. Taylor \& Francis, 0211. doi: 10.1080/19390211.2018.1455788.

Rajkumar, H. et al. (2014) 'Effect of Probiotic (VSL\#3) and Omega-3 on Lipid Profile, Insulin Sensitivity, Inflammatory Markers, and Gut Colonization in Overweight Adults: A Randomized, Controlled Trial', Mediators of Inflammation. doi: 10.1155/2014/348959.

'Rangueil Institute of Molecular Medicine, I 2 MR, U858 Inserm, IFR31, Toulouse, France, 2 Inserm U558, Toulouse, France' (2009) BioScience, (6), pp. 5107-5117.

Rowland, I. et al. (2010) 'Current level of consensus on probiotic science report of an expert meeting- London, 23 november 2009', Gut Microbes, 1(6), pp. 436-439. doi: 10.4161/gmic.1.6.13610.

Stenman, L. K., Holma, R. and Korpela, R. (2012) 'High-fat-induced intestinal permeability dysfunction associated with altered fecal bile acids', World Journal of Gastroenterology, 18(9), pp. 923-929. doi: 10.3748/wjg.v18.i9.923.

Vyas, U. and Ranganathan, N. (2012) 'Probiotics , Prebiotics , and Synbiotics : Gut and Beyond', 2012. doi: $10.1155 / 2012 / 872716$.

Yadav, H. et al. (2013) 'Beneficial metabolic effects of a probiotic via butyrate-induced GLP-1 hormone secretion', J Biol Chem, 288(35), pp. 25088-25097. doi: doi:10.1074/jbc.M113.452516. PMID:23836895. 